\title{
CONTROVÉRSIAS NUMA AÇÃO JUDICIAL DE USUCAPIÃO DE ÁREA URBANA: REFLEXÕES A PARTIR DE UM PROCESSO DE CAXIAS DO SUL - RS
}

\section{CONTROVERSIES IN A LAWSUIT OF USUCAPIÃO OF URBAN AREA: REFLECTIONS FROM A PROCESS OF CAXIAS DO SUL - RS}

\section{Aparecida Veloso Pereira ${ }^{1}$}

\section{Resumo}

O presente artigo objetiva analisar um processo judicial de usucapião de área urbana como forma de adquirir a propriedade de um imóvel e discute, basicamente, divergências entre a legislação municipal, leis federais e a Constituição Federal. Os pedidos da referida ação foram indeferidos em primeira e segunda instância, o que gerou um recurso extraordinário, julgado no Supremo Tribunal Federal (RE 422349/RS) garantindo o direito de usucapir. A metodologia utilizada foi da pesquisa qualitativa, por ser descritiva e pesquisa exploratória por trazer uma reflexão teórica e estudo de caso. O estudo baseia-se em um processo judicial originário de Caxias do Sul-RS, iniciado em 2001 e encerrado em 2018. Após referencial teórico que aborda os conceitos de usucapião urbana e o contexto de posses e propriedades no planejamento urbano e após um breve histórico do processo objeto do estudo de caso, obteve-se como resultado que a supremacia da Constituição Federal impõe-se nos casos concretos, mesmo sem a declaração de inconstitucionalidade de uma lei municipal. Como contribuição destaca-se a importância de pleitear direitos constitucionalmente garantidos em instâncias superiores e, como indicativo para estudos futuros, a necessidade de maior abrangência do tema de planejamento e zoneamento urbano nas cidades.

Palavras-chave: Usucapião; área urbana; recurso extraordinário; função social; propriedade.

\section{Abstract}

The present article aims to analyze a judicial process of usucapião of urban area as a way to acquire ownership of a property and discusses, basically, divergences between the municipal

${ }^{1}$ Doutoranda em Gestão do Espaço Urbano pelo programa de Pós-Graduação em Arquitetura e Urbanismo/UFF; Mestre em Defesa e Segurança Civil/UFF; pós-graduada em Direito Civil e Processo Civil/OABRJ; Pós-Graduada em Planejamento, Implementação e Gestão em Educação à Distância/UFF; graduada em Direito/UBM. E-mail: aparecidaveloso@gmail.com 
legislation, Federal laws and the Federal Constitution. The requests for such action were dismissed in the first and second instance, which resulted in an extraordinary appeal, adjudicated in the Federal Supreme Court (RE 422349 / RS) guaranteeing the right to usucapir. The methodology used was qualitative research, for being descriptive and exploratory research for bringing a theoretical reflection and case study. The study is based on a judicial process originating in Caxias do Sul - RS, started in 2001 and ended in 2018. After theoretical reference that addresses the concepts of urban usucapião and the context of possessions and properties in urban planning and after a brief history of the process that was the object of the case study, it was obtained as a result that the supremacy of the Federal Constitution is imposed in concrete cases, even without the declaration of unconstitutionality of a municipal law. As a contribution, the importance of claiming constitutionally guaranteed rights in higher instances and, as an indication for future studies, the need for greater coverage of urban planning and zoning in cities is important.

Keywords: Usucapião; urban area; extraordinary appeal; social role; property.

\section{INTRODUÇÃO}

A ação de usucapião vem sendo utilizada, de forma frequente, para adquirir a propriedade de um imóvel. No caso em análise, trata-se de uma ação judicial em que os autores que pleitearam o direito à propriedade já possuíam a posse, ou seja, já residiam no imóvel por um lapso de tempo que, conforme determina a legislação, Ihes garantia esse direito. $O$ único requisito impeditivo era a legislação municipal, que determinava como parâmetro de planejamento local, uma metragem mínima para os terrenos destinados à moradia superior à metragem definida na Constituição Federal para usucapião urbano.

Se, por um lado a lei municipal de Caxias do Sul determinava que a área mínima dos lotes residenciais fosse de $360 \mathrm{~m}^{2}$, por outro, e não menos relevante, a Constituição Federal (CF/88) no art. 183, o Código Civil (Lei no 10406/2002) no art. 1240 e o Estatuto da Cidade (Lei no 10.257/2001) no art. 9o estabelecem que aquele que possuir como sua, área urbana de até $250 \mathrm{~m}^{2}$ quadrados, por cinco anos, ininterruptamente e sem oposição, utilizando-a para sua moradia ou de sua família, adquirir-Ihe-á o domínio, ou seja, trata-se do direito de usucapir o imóvel urbano, desde que não seja proprietário de outro imóvel urbano ou rural. O processo 
não pretendia declarar a inconstitucionalidade da lei municipal apenas pleiteava o direito a um imóvel que possuía uma metragem de $225 \mathrm{~m}^{2}$.

É importante destacar que se torna relevante a discussão por ser o direito à moradia um direito fundamental, conforme a Constituição da República Federativa do Brasil de 1988, que em seu Título II, relaciona os Direitos e Garantias Fundamentais. Este título se subdivide em cinco capítulos, sendo que o Capítulo II trata dos direitos sociais e prevê: "Art. 6 o São direitos sociais a educação, a saúde, a alimentação, o trabalho, a moradia, o transporte, o lazer, a segurança, a previdência social, a proteção à maternidade e à infância, a assistência aos desamparados, na forma desta Constituição". Sendo a moradia um direito social e uma garantia fundamental prevista na Carta Magna brasileira será possível observar a dificuldade de acesso ao solo urbano, principalmente por pessoas com menor poder aquisitivo.

Pretende-se analisar as questões controvertidas no julgamento do recurso extraordinário, somadas às discussões dos juristas, bem como os conceitos principais dos institutos jurídicos e temas urbanísticos aqui tratados.

Para tal, o estudo visa abordar o tema explorando, sucintamente e de forma gradual, os seguintes assuntos: usucapião de área urbana; posse e propriedade; planejamento urbano municipal e estudo de caso, para ao final, observar no resultado de que forma a decisão adequou a norma municipal à Constituição Federal, ao Código Civil e ao Estatuto da Cidade.

\section{A USUCAPIÃO DE ÁREA URBANA}

Para entender o instituto, necessário se faz observar o direito de propriedade, que segundo o jurista José Afonso da Silva é um direito positivo que tem seu conteúdo fixado na lei ordinária e "institucionalmente garantido pela Constituição" (SILVA, 2012, p. 71). Continua o autor dissertando que a propriedade não é um instituto único, mas vários institutos diferentes, como a propriedade urbana e a rural, a privada e a pública, a de uso residencial e a de uso industrial, dentre outros. Também destaca que a utilização do solo urbano está sujeita aos planos diretores e à legislação urbanística das cidades, de acordo com o art. 182 da CF/88, o que instrumentaliza o processo de planejamento das cidades.

A propriedade urbana está condicionada ao direito urbanístico e para cumprir sua função social precisa proporcionar condições de circulação, recreação e trabalho, que são as 
funções da cidade, segundo a Carta de Atenas $^{2}$, e garantir também habitação para seus moradores. As chaves do urbanismo estão nas quatro funções habitar, trabalhar, recrear (nas horas livres) e circular ${ }^{3}$. Os moradores das cidades precisam do solo urbano e segundo Leitão e Lacerda, esse uso da propriedade para moradia, "passa a legitimar a posse, provocando o reconhecimento do direito de propriedade" (2003, p. 66). As autoras também destacam que

A usucapião não se tem firmado como um instrumento eficaz no sentido de contribuir para o alcance da cidadania. O número de ações judiciais individuais tem sido inexpressivo frente à magnitude de terras urbanas privadas ocupadas ilegalmente. (LEITÃO e LACERDA, 2003, p. 69).

A ocorrência de ocupação de áreas urbanas para moradia, sem nenhum tipo de registro, ou seja, através da posse mansa e pacífica é muito frequente em diversas cidades brasileiras. A família se instala num terreno, constrói sua casa, habita por anos e não há nenhum tipo de intervenção nem por parte do proprietário privado e nem por parte do poder público municipal. Essa situação fática, leva ao conceito de usucapião de área urbana, conforme art. 183 da Constituição Federal de 1988 - CF/88:

Art. 183. Aquele que possuir como sua área urbana de até duzentos e cinqüenta metros quadrados, por cinco anos, ininterruptamente e sem oposição, utilizando-a para sua moradia ou de sua família, adquirir-Ihe-á o domínio, desde que não seja proprietário de outro imóvel urbano ou rural.

Para Alfonsin este artigo da CF/88 é o reconhecimento da falência da política habitacional brasileira, já que está implícita em sua redação que milhares de famílias ocupam terrenos vazios, pois falta uma política habitacional direcionada para a população de baixa renda e, como conseqüência, o artigo reconhece o direito que emerge do fato dessas famílias terem ocupado esses terrenos e garantem que elas possam permanecer no local, adquirindo a propriedade (ALFONSIN, 2003, p. 168).

Para adquirir o direito de propriedade necessária se faz uma ação judicial. A usucapião é uma modalidade de aquisição da propriedade e um instituto do Direito Civil, ou seja, "é a transformação da posse prolongada e pacífica em domínio" (CARMONA, 2010, P. 78). É o Estatuto da Cidade (Lei no 10.257/2001), que confirma a definição (Art. 99), nos mesmos termos da CF/88 e do CC/02, e estabelece também em seu art. 13 que a sentença que a reconhecer valerá como título para registro no cartório de registro de imóveis, sanando qualquer

\footnotetext{
2 Manifesto urbanístico resultante do IV Congresso Internacional de Arquitetura Moderna (CIAM), realizado em Atenas em 1933, disponível em https://pt.wikipedia.org/wiki/Carta_de_Atenas acesso em 23/01/2017.

3 Disponível em portal.iphan.gov.br/uploads/ckfinder/arquivos/Carta\%20de\%20Atenas\%201933.pdf Acesso em 23/01/2017.
} 
determinação em contrário que possa impedir o registro. Para Afonso e Almendra (2003, p. 17) a ação de usucapião é a maneira adequada de regularizar a propriedade de um lote, portanto, é necessário que o detentor da posse busque a prestação jurisdicional para transformá-la em propriedade.

Vale ressaltar, a título de informação, que "a usucapião encontra vedação constitucional para ser promovida sobre imóveis públicos, mas é admitida pela jurisprudência dos tribunais superiores sobre bens de sociedades de economia mista (...) e, ainda, sobre bens sem domínio definido (...)" (HOSHINO, MEIRINHO e COELHO, 2017, p. 972). No caso em análise, o imóvel pertencia a uma pessoa física, e foi ocupado, segundo os autores da ação, a partir do ano de 1991, ou seja, tinham posse do imóvel na data da propositura da ação, no ano de 2001, sendo cabível a usucapião.

$\mathrm{Na}$ ação de usucapião de área urbana desse estudo de caso, as sentenças de primeiro e segundo grau não reconheceram esse direito, devido ao tamanho do lote, por não ter a metragem estabelecida na legislação municipal, qual seja, $360 \mathrm{~m}^{2}$ (trezentos e sessenta metros quadrados). Para que a ação fosse possível era necessária a comprovação da posse mansa e pacífica pelo lapso de tempo (cinco anos) exigido na legislação e a posse foi devidamente provada tendo os autores direito à propriedade, conforme se esclarece a seguir.

\section{POSSE E PROPRIEDADE}

É mister que sejam definidos e diferenciados esses dois termos, para maior compreensão dos direitos amparados pela ação judicial em comento, quais sejam: a propriedade e a posse. Para tal, observa-se a necessidade de conceituar o proprietário como aquele que possui o título, a documentação que comprova a propriedade do imóvel e como possuidor aquele que não possui o título, mas usa o imóvel sem oposição, com ânimo de possuí-lo.

Ao dissertar sobre as mudanças ocorridas no direito à propriedade, ao longo da história, Torres (2009) destaca três momentos marcantes que a caracterizaram:

A propriedade feudal; a passagem da propriedade feudal para a propriedade democratizada após a revolução francesa, estribada em ideais liberais, considerada propriedade burguesa, sob o domínio pleno e ilimitado de seu titular e o terceiro, ainda em conformação, o reconhecimento de uma propriedade funcionalizada, como um instituto voltado para o atendimento do homem como pessoa e não simplesmente 
como o bem de seu patrimônio ou como riqueza particular. (TORRES, 2009, p. 83).

Como determina a Constituição Federal a propriedade tem uma função social e essa funcionalidade se traduz em utilização por quem dela precisa em detrimento de quem a abandona ou subutiliza.

A propriedade como destaca Silva (2012) está vinculada a princípios constitucionais ${ }^{4}$ que determinam que a propriedade cumpra a sua função social e não anulam a instituição da propriedade privada:

O princípio da função social não autoriza suprimir, por via legislativa, a instituição da propriedade privada. Por outro lado, em concreto, o princípio também não autoriza esvaziar a propriedade de seu conteúdo essencial mínimo, sem indenização, porque este está assegurado pela norma de sua garantia. (SILVA, 2012, p. 75).

Significa que, embora a propriedade tenha que cumprir a sua função social, para tal, alguns requisitos são necessários. Para a retirada da propriedade de seu antigo possuidor, como por exemplo, terrenos não edificados, subutilizados ou não utilizados, conforme prevê o art. $182 \S 4$ e e seus incisos, o poder público municipal deve exigir que o proprietário promova seu adequado aproveitamento sob pena de parcelamento ou edificação compulsórios, IPTU progressivo no tempo e desapropriação. Mas se o poder público não aplica essas sanções e um particular se utiliza da propriedade ociosa para sua moradia, não tendo oposições, com o passar de cinco anos adquire o direito de pleitear a propriedade através da referida ação de usucapião.

O Código Civil, Lei no 10.406/2002 traz regras sobre a posse de imóveis: “Art. 1.196. Considera-se possuidor todo aquele que tem de fato o exercício, pleno ou não, de algum dos poderes inerentes à propriedade". Esses poderes inerentes à propriedade também estão definidos no Código Civil, ou seja, o proprietário tem o direito de usar, gozar e dispor da coisa (Art. 1228).

Nas palavras de Ihering (1976, p. 76) posse é a exteriorização, a visibilidade da propriedade. Para Nascimento, (2000, p. 13) a posse se caracteriza pela utilização do imóvel, ou seja, o proprietário pode ter ou não a posse, pois esta é uma atividade. Já a propriedade é a causa eficiente desta atividade e não estão, posse e propriedade, no mesmo plano. "Uma, a propriedade, é causa, título; a outra, a posse, é efeito não necessário, mas possível" (NASCIMENTO, 2000, P. 13). O mesmo autor narra que "a posse forma-se antes de ser pensada juridicamente. Estrutura-se no mundo dos fatos e, neste sentido, se realiza" (NASCIMENTO, 2000, p. 48).

\footnotetext{
${ }^{4}$ Art. 5o, XXIII da CF/88
} 
Há uma abordagem do princípio da função social da propriedade que amplia a definição de propriedade também como posse, ou seja, considera-se proprietário também quem tem um título de posse, ou quem, mesmo sem título usufrui de uma propriedade sem oposições, de forma mansa e pacífica. A CF/88 promove e busca a valorização da pessoa humana e eleva os conceitos de cidadania, essa reflexão faz parte o pensamento de Albuquerque (2002), que também apresenta a seguinte fórmula: "A propriedade tem função social. A posse é semelhante à propriedade. A posse tem função social" (ALBUQUERQUE, 2002, p. 38). A autora também disserta que: "Em nosso país, a realidade social vem ditando a importância da posse, e, com isso, cresce o número de decisões judiciais onde a mesma é protegida por sua função social" (ALBUQUERQUE, 2002, p. 219).

Em consonância com esses argumentos, Pereira (2009) ressalta que a posse é "um instrumento através do qual a função social da propriedade se efetiva. É, portanto, a razão de ser da propriedade, o elemento que dá a ela conteúdo e relevância" (PEREIRA, 2009, p. 167) e acrescenta:

Uma sociedade orientada pelos valores sociais e ditames de justiça de priorizar o direito daquele que, de fato, dá destinação econômica e social à coisa. Nesta sociedade não cabe utilizar os textos legais para proteger $\mathrm{o}$ individualismo e a propriedade privada, deixando de lado um enorme número de sem-tetos e sem trabalho. $O$ direito deve ser um instrumento de promoção social e não de segregação, e a posse apresenta-se como um mecanismo capaz de viabilizar tal função (PEREIRA, 2009, p. 167).

Um dos objetivos da política urbana é "ordenar o pleno desenvolvimento das funções sociais da cidade e garantir o bem-estar de seus habitantes", isto também está previsto no art. 182 da CF/88. Portanto a propriedade urbana deve cumprir sua função social e quando o poder público municipal não se manifesta, nem o proprietário privado, e um terreno é utilizado por uma família por cinco anos sem oposição, cumprindo os demais requisitos para uma ação de usucapião, o particular também está contribuindo para que essa propriedade e a cidade cumpram a função social, que conforme a lei, devem cumprir. Ressalta-se que Albuquerque (2002) menciona a colisão entre o princípio função social da posse e o da função social da propriedade, quando há casos discutindo interesses do proprietário que não exerce o direito de propriedade e o possuidor dotado do direito de posse. Argumenta que os dois princípios encontram-se em patamar de igualdade e isto significa: "a possibilidade de existência de uma colisão entre ambos a ser solucionada no caso concreto pelo princípio da proporcionalidade dos bens, exigindo a ponderação de bens e valores por parte do julgador" (ALBUQUERQUE, 2002, 
p.211). Destaca também quando se trata de ações dessa natureza que necessário se faz a observância dos princípios da igualdade e da dignidade da pessoa humana.

Conforme estudo de Dourado (2003, p. 478) “Nos últimos anos, tem-se fortalecido o princípio da função social da propriedade, em detrimento do pensamento individualista prevalecente e instituído pelo Código Civil no que tange à propriedade", tendo em vista que o Código $\mathrm{Civi}^{5}$ prevê a propriedade como um direito real; assim como na CF/88 está previsto que é garantido o direito de propriedade. Entende-se por direito real um direito que o proprietário tem de reaver o imóvel de quem injustamente o detenha, por exemplo, através da ação de reintegração de posse ${ }^{6}$. Também é o direito real mais forte que os direitos pessoais, pois garante a preferência ${ }^{7}$. Mas, é importante ressaltar que há outros direitos reais quando se trata de posse e propriedade. O Art. 1225 do Código Civil destaca como direitos reais, dentre outros, a propriedade, o uso, o usufruto, a habitação. Portanto, quem utiliza um imóvel, sem oposição, vivencia a posse do mesmo e passa a ter direitos reais no mesmo patamar de um proprietário.

No entanto, com a função social da propriedade, como princípio constitucional, o proprietário de um imóvel urbano não pode deixar de utilizá-lo, subutilizado ou não edificá-lo, tendo como base que o seu direito real de propriedade está garantido. É preciso que essa propriedade seja utilizada para que cumpra sua função social, pois também a cidade tem suas funções sociais, assim como é uma garantia constitucional o bem-estar dos seus habitantes. Essas são algumas das responsabilidades da gestão pública municipal e devem fazer parte de um planejamento. A discussão da ação de usucapião aqui analisada é, justamente, sobre um parâmetro de planejamento urbano municipal, utilizado na legislação de Caxias do Sul, que definiu a metragem dos terrenos residenciais, e que, embora tenha uma relevância, parece não dialogar com a realidade local.

\section{PLANEJAMENTO URBANO MUNICIPAL}

Para o melhor ordenamento do território urbano seria necessário o devido planejamento, mas é de conhecimento geral que as cidades brasileiras crescem sem esse
Art. $\quad 1225 \quad$ da
Lei $\quad 10406 / 2002$
(CC/02)
disponível
em http://www.planalto.gov.br/ccivil_03/leis/2002/L10406.htm Acesso em 15/02/2017
${ }^{6}$ Ação para devolver uma área ocupada ao seu legítimo proprietário. (art. 560 a 566 do Código de Processo Civil, Lei 13.105/2015 disponível em http://www.planalto.gov.br/ccivil_03/_ato2015- 2018/2015/lei//13105.htm Acesso em 15/02/2017.
${ }^{7}$ Disponível em http://rafaeldemenezes.adv.br/aulas/direitos-reais/7 Acesso em 15/02/2017 
devido plano, sem previsão da proporção do aumento da população. Conforme Hoshino, Meirinho e Coelho (2017, p. 972) "A oposição entre o estado das cidades brasileiras e aquilo que projetam as normas para o espaço urbano é um grande desafio do urbanismo e do direito urbanístico contemporâneos". Mesmo os municípios que possuem normas relativas ao planejamento urbano, podem não conseguir atingir a realidade local de forma abrangente e satisfatória.

Pode-se dizer que o planejamento urbano, atualmente, objetiva fazer a cidade se tornar mais empreendedora e competitiva, de um modo geral e seguindo um modelo dentro da nova ordem mundial, mas sem a total contribuição dos estudiosos de urbanismo para a elaboração dos mesmos, é o que observa Machado (2003, p. 950) ao analisar um exemplo de plano estratégico brasileiro. Em outras palavras, para um planejamento urbano eficaz deveria haver uma reunião de saberes, com contribuições dos vários atores envolvidos, como urbanistas, arquitetos, juristas, técnicos, população, políticos, ambientalistas, gestores públicos, administradores, dentre outros. Nessa mesma linha de raciocínio, Guimarães (2017) destaca que o direito à cidade se relaciona com seus moradores e trabalhadores, deve ser definido por processos de participação de quem produz no espaço urbano e "pelas experiências, inclusive as práticas espontâneas vivenciadas na cidade. Ele está marcado pelo poder de alteração e decidir, de modo amplo, os destinos e projetos para o espaço urbano" (GUIMARÃES, 2017, p. 632).

Conforme estudo de Souza (2015, p.47) ao tentar planejar é preciso o esforço de imaginar o futuro. O planejamento necessita de uma reflexão prévia sobre o quadro atual. Para o autor a sociedade é autocriada e o termo planejamento não pode ser substituído por gestão, como alguns autores defendem, como também não são sinônimos os termos planejamento urbano e urbanismo e argumenta que o planejamento urbano "inclui" o urbanismo (SOUZA, 2015, p. 58). Para melhor explicar ressalta que "a partir do momento em que se assume que a finalidade do planejamento e da gestão urbanos é contribuir para a mudança social positiva", o planejamento é uma estratégia de desenvolvimento sócio-espacial (SOUZA, 2015, p.73).

Planejar alguma coisa significa preconceber, ou seja, para fazer um planejamento seria necessário projetar a cidade, antes de sua criação, o que não ocorre e faz com que o planejamento urbano municipal traga esse vício: planejar uma cidade que já existe, com todos os seus problemas, desigualdades e desordens.

Numa análise mais abrangente, Aguiar e Miranda (2014, p. 52 e 53) destacam que "o planejamento urbano é uma área que sobrepuja os conceitos de urbanismo e desenho urbano, mas é bem verdade que o desenho urbano e o urbanismo estão imersos dentro do contexto de 
planejamento urbano". Os mesmos autores salientam que o planejamento urbano aparece "como uma forma de conter os avanços de aglomeração urbana e ao mesmo tempo proporcionar o desenvolvimento igualitário da cidade" e fazem uma comparação entre planejamento e gestão, relatando que é preciso a comunhão de ambos para um planejar, projetar e o outro gerir o perímetro urbano planejado, com ações que lidem com os problemas da "imprevisibilidade da vida urbana" (AGUIAR e MIRANDA, 2014, p.53). Por fim os autores reconhecem que o planejamento deveria ser anterior à formação das cidades, destacam a reforma urbana como um ideal, mas precisa ser entendida como reforma social, pois deveria haver a distribuição igualitária dos espaços para erradicar as desigualdades sociais.

Há também outro modelo de planejamento das cidades, com um termo muito utilizado ultimamente por gestores e prefeitos, o planejamento estratégico, que no entender de Sanches (1999) "Seus conceitos, doutrina e instrumentos analíticos e metodológicos são extraídos da prática empresarial". Segundo a mesma autora, numa breve avaliação, "algumas estratégias são priorizadas em detrimento de outras, à mercê da correlação de forças e dos interesses em jogo na definição do que seja "mais" ou "menos" estratégico" (SANCHES, 1999, p.122). Portanto, nem sempre o planejamento estratégico torna-se um planejamento urbano útil para todos.

Por outro lado, ressalta Rolnik (2006) que a construção de cidades mais equilibradas, justas e eficientes precisa de implementação de políticas urbanas que (...) "introduzam mecanismos permanentes de acesso à terra legal e formal por parte dos mais pobres, redesenhando a natureza e instrumentos até agora em vigor no campo do planejamento e gestão do solo urbano em nossas cidades" (ROLNIK, 2006, p.201). Ao abordar o tema da moradia para a população de baixa renda e o planejamento urbano destaca que:

A agenda do planejamento urbano e regulação urbanística na maior parte das grandes cidades brasileiras ainda esteve muito mais voltada para a cidade formal, das classes médias e dos médios e grandes empreendedores, do que dialogando com os mercados de baixa renda (ROLNIK, 2006, p. 204).

Uma questão levantada por Souza, de o planejamento objetivar uma mudança social positiva (2015, p. 73) iria de encontro com essas políticas públicas mencionadas por Rolnik (2006, p.201), pois se houvesse, no planejamento, estratégias para atender também às famílias com menor poder aquisitivo, com certeza haveria mudanças sociais positivas e cidades mais justas. 
O direito urbanístico também contribui para direcionar e priorizar questões relativas ao planejamento urbano. É pertinente salientar que o Estatuto da Cidade, Lei 10.257/2001, estabelece diretrizes em seu art. 4ㅇ para o planejamento municipal, em especial:

a) plano diretor; b) disciplina do parcelamento, do uso e da ocupação do solo; c) zoneamento ambiental; d) plano plurianual; e) diretrizes orçamentárias e orçamento anual; f) gestão orçamentária participativa; g) planos, programas e projetos setoriais; h) planos de desenvolvimento econômico e social.

Explica melhor no art. 40, $\S 1$ ㅇq que "o plano diretor é parte integrante do processo de planejamento municipal, devendo o plano plurianual, as diretrizes orçamentárias e o orçamento anual incorporar as diretrizes e as prioridades nele contidas". Significa que o município precisa ter um plano diretor abrangente e executável através de seu orçamento e para tal, precisa definir prioridades, e dentre outras funções, planejar e disciplinar o parcelamento, o uso e a ocupação do solo.

Prevê a Constituição Federal, no seu art. 30, inciso VIII que compete aos municípios "promover, no que couber, adequado ordenamento territorial, mediante planejamento e controle do uso, do parcelamento e da ocupação do solo urbano". Já a Lei Federal no 6.766, de 19 de dezembro de 1979 que dispõe sobre o Parcelamento do Solo Urbano, estabelece no art. 4으, §1ㅇq que:

A legislação municipal definirá, para cada zona em que se divida o território do Município, os usos permitidos e os índices urbanísticos de parcelamento e ocupação do solo, que incluirão, obrigatoriamente, as áreas mínimas e máximas de lotes e os coeficientes máximos de aproveitamento. (Redação dada pela Lei no 9.785, de 1999).

Especificamente, sobre planejamento municipal Furtado e Rezende (2012) observam, que: "A política urbana municipal deve conter parâmetros de uso e aproveitamento do solo, através de um Macro zoneamento que defina zonas adensáveis, zonas de incentivo e de controle, de conservação, de proteção, a demarcação das centralidades". Também destacam as autoras que "são atribuições municipais a delimitação do perímetro urbano e a definição de áreas e condições para a expansão urbana" (FURTADO e RESENDE, 2012, p. 212).

Por fim, prevê a Lei 6.766/79, no art. 40 inciso II que os lotes terão área mínima de $125 \mathrm{~m}^{2}$ (cento e vinte e cinco metros quadrados). Significa, portanto, que a lei municipal que define metragem mínima para lotes residenciais de $360 \mathrm{~m}^{2}$ não está ferindo nenhum ordenamento jurídico quanto ao mínimo, porém ao fixar uma metragem superior a $250 \mathrm{~m}^{2}$ não observou a Constituição Federal, o Estatuto da Cidade e o Código Civil, ou seja, a legislação federal e constitucional deveria ter sido considerada no planejamento urbano municipal, 
principalmente para efeito de ações de usucapião urbana. Conforme Ferraz (2007) no Estatuto da Cidade há "um incentivo ao planejamento urbano, com uma maior valorização do Plano Diretor. Dessa forma são determinados os instrumentos da política urbana, dentre os quais os institutos jurídicos e políticos, onde se encontra a usucapião especial urbana" (FERRAZ, 2007, p. 20). Enquanto instrumento de planejamento urbano, o Plano Diretor e as leis municipais de parcelamento do solo são eficazes, apenas cabe aqui uma crítica com relação à lei municipal não prever a usucapião urbana, de forma adequada à Constituição Federal.

\section{ESTUDO DE CASO}

Trata-se de uma ação judicial proposta por um casal na cidade de Caxias do Sul, em 2001, que foi julgada improcedente na primeira instância, em março de 2003 e foi enviada a apelação ao Tribunal de Justiça do Rio Grande do Sul, que também a julgou improcedente, em setembro de 2003. Em 2004 foi enviado um Recurso Extraordinário - RE ao Supremo Tribunal Federal - STF, por entenderem os autores que houve afronta à Constituição Federal, que foi julgado procedente, decisão esta, de 2015.

O Recurso Extraordinário é o instrumento jurídico utilizado para contestar as decisões de primeira e segunda instância quando forem contrárias à Constituição Federal, ou seja, o processo é julgado em instância superior.

Prevê a Constituição Federal, no seu artigo 102 que compete "ao Supremo Tribunal Federal, precipuamente, a guarda da Constituição, cabendo-Ihe:", conforme inciso "III - julgar, mediante recurso extraordinário, as causas decididas em única ou última instância, quando a decisão recorrida:"

a) contrariar dispositivo desta Constituição; b) declarar a inconstitucionalidade de tratado ou lei federal; c) julgar válida lei ou ato de governo local contestado em face desta Constituição. d) julgar válida lei local contestada em face de lei federal. (Incluída pela Emenda Constitucional no 45, de 2004).

Portanto, o recurso extraordinário é uma forma de levar uma ação judicial julgada improcedente na primeira instância (cidade da propositura da ação) e na segunda instância (RS Estado da propositura da ação) para julgamento na instância superior ou última instância (Brasília - capital do país). Nesse momento processual as partes não podem mais apresentar documentos, mas todo o processo, com todos os documentos anexados, termos de audiências, atas, decisões, termos de oitiva de testemunhas são analisados pelos ministros do STF. 
O recurso extraordinário é um dos recursos cabíveis nos processos e está previsto na Lei no 13.105/2015, novo Código de Processo Civil, art. 994, inciso VII. De acordo com Mendes (2004) "O recurso extraordinário consiste no instrumento processual constitucional destinado a assegurar a verificação de eventual afronta à Constituição em decorrência de decisão judicial proferida em última ou única instância do Poder Judiciário" (MENDES, 2004, p. 11). De acordo com Miguel (2015) "o recurso extraordinário tem como finalidade maior manter a autoridade soberana e a unidade de interpretação da Constituição da República" (MIGUEL, 2015, s.p.). Uma lei municipal não pode ser aplicada sem observância da Constituição Federal, sendo cabível o recurso extraordinário não para declarar a inconstitucionalidade da lei, visto que esse não foi o pedido dos autores, mas para assegurar que a Constituição Federal tenha a sua autoridade mantida de forma soberana.

Quando o STF conhecer do recurso extraordinário, para efeito da repercussão geral, precisa considerar a existência, ou não, de questões relevantes do ponto de vista econômico, político, social ou jurídico, que ultrapassem os interesses subjetivos da causa, conforme art. 1035, §1으 da Lei 13/105/2015. Causas que versem sobre o mesmo tema já terão o acórdão (decisão do STF) como parâmetro, conforme §50 do mesmo artigo "Reconhecida a repercussão geral, o relator no Supremo Tribunal Federal determinará a suspensão do processamento de todos os processos pendentes, individuais ou coletivos, que versem sobre a questão e tramitem no território nacional". Ou seja, publica-se uma súmula (resumo) que vincula os outros processos à mesma decisão.

Os autores entenderam que as decisões de primeira e segunda instância contrariaram dispositivo da Constituição, razão principal do recurso extraordinário, embora a abrangência do mesmo, ao final, tenha sido maior, devido ao debate e à relevância do acórdão com repercussão geral, que será mais adiante detalhada.

Assim como muitas cidades brasileiras, Caxias do Sul teve um grande aumento da população urbana, o que gera demanda por moradia. Segundo o Instituto Brasileiro de Geografia e Estatística (IBGE), em 2010, Caxias do Sul possuía 235 mil habitantes e segundo estimativa do mesmo órgão no ano de 2013 estaria com 465 mil e para 2015 estimou-se 500 mil habitantes. A TV Caxias $^{8}$ informou que no ano de 2014, Caxias do Sul possuía 470.223 habitantes.

\footnotetext{
${ }^{8}$ Disponível em http://www.tvcaxias.com.br/noticia/visualizar/780 acesso em 09/02/2017
} 
A cidade tem uma vasta legislação sobre planejamento urbano e possui, dentre outras normas, o Plano Diretor (a Lei Complementar no 290, de 24 de setembro de $2007^{9}$ ) e a lei municipal $n$ ㅇ 6.810, de 20 de dezembro de 2007 que disciplina o parcelamento do solo para fins urbanos, a regularização fundiária sustentável e dá outras providências e prevê que a legislação municipal observará a legislação federal e estadual pertinentes:

Art. 1 o O parcelamento do solo para fins urbanos e a regularização fundiária sustentável de área urbana regem-se por esta Lei, denominada Lei do Parcelamento do Solo, observadas, no que couberem, as disposições da legislação federal e estadual pertinentes.

Esta lei revogou a lei municipal no 3.300/88 (em vigor na propositura da ação), que disciplinava o parcelamento do solo, para fins urbanos (Capítulo II, Seção II).

Como a ação foi distribuída, ou seja, como o processo do estudo de caso foi iniciado no dia 28/12/2001, necessário se faz observar quais eram as leis vigentes nessa data. A lei federal de parcelamento de solo (Lei no 6.766/79) que estabelece a metragem mínima de $125 \mathrm{~m}^{2}$ e a Lei Municipal no 3.300/88 que estabelecia no Capítulo II, Seção II que "os lotes resultantes do parcelamento deverão obedecer aos seguintes padrões urbanísticos: I - Residenciais: Área mínima: 360,00m2" estavam em vigor. O Plano Diretor que estava vigente era a LC no27/96.

O Recurso extraordinário (RE 422349/RS) é a continuidade da ação judicial de usucapião, que em primeira instância, foi proposta perante a 4a Vara Cível da Comarca de Caixas do Sul, que não esta qualificada como "segredo de justiça" sendo possível a consulta do processo através do site do Tribunal de Justiça do Rio Grande do Sull ${ }^{10}$, bem como o recurso extraordinário, pode ser consultado na página eletrônica do STF ${ }^{11}$.

Após sentença de primeiro grau em 05/03/2003, em que o pedido dos autores foi negado por contrariar lei municipal, os autores recorreram à segunda instância. A 20a Câmara Cível do Tribunal de Justiça do Rio Grande do Sul - TJRS decidiu não prover a apelação entendendo que é de competência do município definir metragem mínima dos terrenos destinados à moradia e decidiu também pela "inaplicabilidade do art. 183 da CF".

Em 16/03/2004 o Recurso Extraordinário foi admitido e o processo foi encaminhado ao STF. Conforme dados do TJRS o processo retornou do STF em 01/09/2015, com recurso extraordinário provido na seção plenária do dia 29/04/2015.

\footnotetext{
${ }^{9}$ A LC no 27 de 15 de julho de 1996. Instituiu o Plano Físico Urbano de Caxias do Sul era o Plano Diretor que estava vigente na propositura da ação. (Revogada pela Lei Complementar no 290/2007).

${ }^{10} \mathrm{http}: / /$ www.tjrs.jus.br/

${ }^{11} \mathrm{http} ; / /$ www.stf.jus.br/
} 
O recurso foi conduzido perante a Primeira Turma da Corte, e essa, por unanimidade, decidiu-se pelo julgamento perante o Tribunal Pleno. As turmas são compostas de cinco ministros e no tribunal pleno todos os onze ministros participam, conforme estabelece o Regimento Interno do STF ${ }^{12}$. A Procuradoria-Geral da República, através do Procurador Dr. Rodrigo Janot, opinou pelo provimento do recurso extraordinário, reconhecendo o direito de usucapir em observância à Constituição Federal.

Uma das principais discussões dos Ministros foi sobre a inconstitucionalidade da lei municipal, mas o relator, Ministro Dias Tófoli afastou essa possibilidade alegando que: "Há que se ressaltar que não se está, nesta oportunidade, declarando a inconstitucionalidade de qualquer norma municipal (...) a decisão objurgada deixou, simplesmente, de aplicar o disposto no art. 183 da Constituição Federal". ${ }^{13}$ Destacou também em seu voto citação de Ribeiro (2008) que merece ser mencionada:

Representativo desse entendimento doutrinário é o seguinte excerto da magistral obra Tratado de Usucapião, volume I, Editora Saraiva, 2008, de autoria do eminente jurista Benedito Silvério Ribeiro: "Cabe ressaltar que a função social da propriedade pode levar a contornar requisitos urbanísticos e mesmo do plano diretor da cidade, sem o rigor inerente ao parcelamento do solo" (p. 942).

Esse argumento também foi acompanhado no voto do Ministro Luiz Fux que declarou que não havia inconstitucionalidade na lei municipal, mesmo fixando o módulo urbano em área superior a $250 \mathrm{~m}^{2}$, "como parâmetro de planejamento e fiscalização da política urbana local, sem que isso impeça ao particular, por sua vez, a aquisição do direito de propriedade de área menor" ${ }^{14}$ E observou que a inconstitucionalidade estava na decisão judicial que deixou de aplicar o artigo 183 da Constituição Federal. Em seu voto destaca:

Além disso, a relevância jurídica e social da questão constitucional ora debatida é inegável, já que envolve o direito fundamental de moradia, o princípio da função social da propriedade e um instituto através do qual ambos se realizam, que é a usucapião especial urbana (p. 35).

Já o Ministro Marco Aurélio, embora tenha reconhecido o direito ao imóvel, por meio da usucapião divergiu do relator no que tange à preservação da legislação municipal, pois entendeu que por ser o lote inferior ao mínimo determinado na legislação urbanística não poderia constituir uma unidade imobiliária autônoma e dissertou que o adquirente se tornaria

\footnotetext{
${ }^{12} \mathrm{http} / / /$ www.stf.jus.br/arquivo/cms/legislacaoRegimentolnterno/anexo/RISTF.pdf

${ }^{13}$ Voto do Sr. Ministro Dias Tófoli (relator) expressa no Inteiro Teor do Acórdão, p. 11 Disponível em http://redir.stf.jus.br/paginadorpub/paginador.jsp?docTP=TP\&docID=9046379 Acesso em 23/01/2017

14 Voto do Sr. Ministro Luiz Fux expressa no Inteiro Teor do Acórdão, p. 34 Disponível em http://redir.stf.jus.br/paginadorpub/paginador.jsp?docTP=TP\&docID=9046379 Acesso em 23/01/2017
} 
proprietário de uma fração ideal do terreno e haveria um condomínio entre o antigo dono e o autor da ação de usucapião, conforme segue:

Conheço do recurso e dou-lhe parcial provimento para reformar o acórdão recorrido, de modo a reconhecer a aquisição, por meio da usucapião, da fração ideal do terreno correspondente à exata proporção da área ocupada, vedando a criação de uma unidade imobiliária autônoma, com matrícula própria no Registro Geral de Imóveis, que seja inferior ao módulo territorial mínimo previsto na legislação municipal ${ }^{15}$.

Embora o posicionamento do Ministro Marco Aurélio tenha sido respeitado pelos demais ministros, o Relator Ministro Dias Tófoli manteve seu voto e argumentou que deveria haver uma matrícula para a metragem de $225 \mathrm{~m}^{2}$, conforme processo de usucapião, pois é esse o resultado de toda ação judicial de usucapião julgada procedente. Abre-se a matrícula com base numa decisão judicial.

Como principais questões teóricas dos votos foi possível destacar no voto do Relator Ministro Dias Tófoli o seguinte argumento: "a presente modalidade de aquisição da propriedade imobiliária foi incluída em nossa Carta como forma de permitir o acesso dos mais humildes a melhores condições de moradia" (RE 422349/RS Inteiro Teor do Acórdão, p. 10 de 71). Também associa ao respeito à dignidade da pessoa humana como um dos fundamentos da República (art. 1ำ, inciso III, da Constituição Federal) e, no caso em análise salienta: "Assim, a desconformidade de sua metragem com normas e posturas municipais que disciplinam os módulos urbanos em sua respectiva área territorial não podem obstar direito constitucionalmente assegurado". Com esse posicionamento o Relator não deixa dúvidas quanto à supremacia da Constituição Federal em detrimento de outras normas. Após expor as razões para o acolhimento do pedido, baseando-se nos argumentos dos autores e na inconteste posse mansa e pacífica pelo lapso temporal exigido no instituto da usucapião, o Relator se posiciona a favor da aplicação da repercussão geral ao julgado, pois dada a relevância da questão do ponto de vista social e jurídico, propõe o reconhecimento da repercussão geral do tema, com a aprovação da seguinte tese: "preenchidos os requisitos do art. 183 da Constituição Federal, o reconhecimento do direito à usucapião especial urbana não pode ser obstado por legislação infraconstitucional que estabeleça módulos urbanos na respectiva área em que situado o imóvel (dimensão do lote)" (RE 422349/RS Inteiro Teor do Acórdão, p. 14 de 71).

O saudoso Ministro Teori Zavascki acompanhou o Relator em seu voto e opinou: "há possibilidade, sim, de preservar a legislação que estabelece a existência de módulos de $360 \mathrm{~m}^{2}$

15 Voto do Sr. Ministro Marco Aurélio expressa no Inteiro Teor do Acórdão, p. 47 Disponível em http://redir.stf.jus.br/paginadorpub/paginador.jsp?docTP=TP\&doclD=9046379 Acesso em 23/01/2017 
(...) Ou seja, manter-se-ia a legislação municipal, exceto nos casos em que incide coercitivamente a força superior da Constituição" (RE 422349/RS Inteiro Teor do Acórdão, p. 25 de 71). Com esse posicionamento, a questão da inconstitucionalidade da lei foi sendo descartada. Para dirimir dúvidas no seu voto, o Ministro Luiz Fux, esclareceu:

Não há, portanto, qualquer inconstitucionalidade na lei municipal que fixa o módulo urbano em área superior a $250 \mathrm{~m}^{2}$, como parâmetro de planejamento e fiscalização da política urbana local, sem que isso impeça ao particular, por sua vez, a aquisição do direito de propriedade de área menor, no caso de o órgão de controle não se insurgir no prazo definido constitucionalmente.

Houve também um debate, iniciado pelo Ministro Luiz Roberto Barroso sobre os demais requisitos da usucapião, que não haviam sido mencionados nem sentença de primeiro grau e nem no acórdão de segundo grau, ficando a questão subentendida, por haver um posicionamento apenas sobre a metragem do lote. O voto do Ministro Luiz Roberto Barroso sobre o tema relata: "De modo que eu acho que a tese jurídica do Ministro Toffoli está correta, mas eu acho que é o caso de se devolver à instância originária para verificar os demais requisitos" (RE 422349/RS Inteiro Teor do Acórdão, p. 53 de 71). Após ampla discussão sobre o tema, em que a maioria dos Ministros continuou acompanhando o Relator, a Ministra Rosa Weber fez a leitura da petição inicial que narrava, com detalhes, que os autores cumpriram todos os requisitos, moravam no imóvel há mais de dez anos sem oposição, não possuíam outro imóvel e juntaram documentos comprobatórios de pagamento de despesas referentes ao imóvel. Todos esses fatos e documentos não foram contestados na fase processual apropriada. Outro posicionamento que encerrou a discussão foi o argumento do Ministro Luiz Fux, citando o Ministro Marco Aurélio, "a preclusão é um instrumento a serviço do caminhar do processo para frente. Então não pode aditar a inicial, não pode formular pedido depois da defesa, e assim vai andando para frente, para evitar a retroação" (RE 422349/RS Inteiro Teor do Acórdão, p. 66 de 71). O Ministro Ricardo Lewandoski (presidente) votou conforme o voto do Relator. "Eu também entendo que a matéria está vencida, no que diz respeito ao preenchimento dos demais requisitos da usucapião" (RE 422349/RS Inteiro Teor do Acórdão, p. 67 de 71).

Por fim, para melhor entendimento do que foi discutido no estudo de caso, segue a decisão dos ministros do STF, somente com as iniciais das partes e seus advogados, em respeito às suas identidades:

ACÓRDÃO ELETRÔNICO REPERCUSSÃO GERAL - MÉRITO DJe-153 DIVULG 04-08-2015 PUBLIC 05-08-2015 RECTE.(S) :A. J. Z. E OUTRO(A/S) ADV.(A/S) :A. U. R. E OUTRO(A/S) RECDO.(A/S) J. A. R. ADV.(A/S): A. B. B. EMENTA Recurso extraordinário. Repercussão geral. Usucapião especial 
urbana. Interessados que preenchem todos os requisitos exigidos pelo art. 183 da Constituição Federal. Pedido indeferido com fundamento em exigência supostamente imposta pelo plano diretor do município em que localizado o imóvel. Impossibilidade. A usucapião especial urbana tem raiz constitucional e seu implemento não pode ser obstado com fundamento em norma hierarquicamente inferior ou em interpretação que afaste a eficácia do direito constitucionalmente assegurado. Recurso provido. 1. Módulo mínimo do lote urbano municipal fixado como área de $360 \mathrm{~m} 2$. Pretensão da parte autora de usucapir porção de $225 \mathrm{~m} 2$, destacada de um todo maior, dividida em composse. 2. Não é o caso de declaração de inconstitucionalidade de norma municipal. 3. Tese aprovada: preenchidos os requisitos do art. 183 da Constituição Federal, o reconhecimento do direito à usucapião especial urbana não pode ser obstado por legislação infraconstitucional que estabeleça módulos urbanos na respectiva área em que situado o imóvel (dimensão do lote). 4. Recurso extraordinário provido.

Importante observar duas questões no acórdão: a tese e a repercussão geral. Na tese, o

Relator destacou que não bastava mencionar que o direito à usucapião não poderia ser obstado por limitações da legislação infraconstitucional, sugerindo o texto acima que coloca entre parênteses "dimensão do lote", pois, conforme disserta na fl. 49 do já referenciado acórdão:

Recebi, Senhor Presidente, contribuições de especialistas nas áreas de direito urbanístico e ambiental que alertaram exatamente para as implicações de se dar uma dimensão maior ao caso. Por exemplo, citando apenas limitações, "não pode ser obstada por limitações da legislação infraconstitucional" ficaria muito amplo, porque não incluiria áreas de risco, de proteção ao meio ambiente, as quais geram outros tipos de restrições. E, como esse caso concreto, se trata da dimensão do lote, que no município foi fixado no mínimo de $360 \mathrm{~m}^{2}$ - ou seja, naquele município não poderia haver usucapião especial urbana nunca, porque a Constituição fala em módulos até $250 \mathrm{~m}^{2}$ para a usucapião especial urbana -, dentro unicamente e exclusivamente do tema do processo é que eu, então, sugeriria esta redação para a fixação de tese numa repercussão geral.

Com a referida mudança na redação da tese os Ministros votaram também a favor da fixação de repercussão geral no acórdão, pois conforme a Lei no 11.418, de 19 de dezembro de 2006, que acrescentava dispositivos ao Código de Processo Civil então em vigor, totalmente recepcionada pelo novo Código Civil, Lei 13.105/2015. Para efeito da repercussão geral, será considerada a existência, ou não, de questões relevantes do ponto de vista econômico, político, social ou jurídico, que ultrapassem os interesses subjetivos da causa. Por maioria de votos os ministros reconheceram a repercussão geral da matéria e fixaram a seguinte tese:

Preenchidos os requisitos do artigo 183 da Constituição Federal, o reconhecimento do direito à usucapião especial urbana não pode ser obstado por legislação infraconstitucional que estabeleça módulos urbanos da respectiva área em que situado o imóvel (dimensão do lote).

Segundo Mendes (2004) a exigência de manifestação sobre a repercussão geral "abre 
promissoras perspectivas para a jurisdição constitucional no Brasil, especialmente quanto à assunção pelo Supremo Tribunal Federal do típico papel de um verdadeiro Tribunal Constitucional" (MENDES, 2004, p. 12). É importante salientar que a tese foi reconhecida como repercussão geral, por ser a questão relevante do ponto de vista social e jurídico, pois os efeitos passam a ser reconhecidos em ações semelhantes, não havendo mais dúvidas quanto à aplicação ou não da Constituição Federal em casos em que a legislação municipal fixa metragem maior que $250 \mathrm{~m}^{2}$ para lotes urbanos. A usucapião será possível e cabível e o acórdão garantirá que o assunto não volte a ser discutido como inédito, ou seja, é direito usucapir terrenos urbanos até $250 \mathrm{~m}^{2}$ devido à previsão constitucional.

Observa-se a importância do reconhecimento da repercussão de um julgado, pois, seus efeitos começarão a partir da publicação do acórdão, ou seja, não fere a legislação municipal com o seu planejamento urbano, que define a metragem mínima dos lotes para fins residenciais, mas também não prejudica moradores de áreas menores de pleitearem seus direitos.

\section{CONSIDERAÇÕES FINAIS}

Foi possível observar que uma ação judicial de usucapião urbana foi utilizada para garantir o direito de propriedade daqueles que possuem a posse mansa e pacífica de uma determinada área, por mais de cinco anos e sem nenhuma oposição. Como forma de regularização da propriedade e como forma de adquiri-la, uma ação de usucapião cumpre a sua função. Tratou-se de divergência entre a legislação municipal, leis federais e a Constituição Federal e não prevaleceu a lei municipal quanto à metragem dos lotes residenciais, mas sim a previsão constitucional. O recurso extraordinário, julgado no Supremo Tribunal Federal (RE 422349/RS) garantiu o direito de usucapir, em detrimento de duas decisões anteriores, de primeiro e segundo grau de jurisdição.

Embora críticas quanto ao tempo de tramitação do processo possam ser feitas, tendo em vista que a ação foi distribuída em 2001 e até a presente data não consta como um feito arquivado, o volume de processos nos tribunais brasileiros é muito grande. Como a usucapião urbana possui como objetivo a regularização do direito fundamental à moradia, seria necessário maior atenção às previsões constitucionais sobre direitos fundamentais, onde é garantido o direito de propriedade e esta deve cumprir a sua função social (art. 5o, XXII e XXIII) já desde a primeira instância. Também prevê que "a todos, no âmbito judicial e administrativo, são 
assegurados a razoável duração do processo e os meios que garantam a celeridade de sua tramitação" (art. 5ํ, LXXVIII). Vale destacar que muitos processos não deveriam ser encaminhados ao STF, pois há recursos utilizados apenas para adiar o cumprimento de sentenças, com a nítida intenção de protelar, são os recursos e agravos manifestamente protelatórios, que sobrecarregam o STF. Por outro lado, a repercussão geral declarada será um precedente para outros processos que, provavelmente, terão um tempo menor de tramitação. No mérito, pode-se dizer que prevaleceu o direito à moradia e a desconformidade da metragem em relação à previsão constitucional não mais será enviada à Corte Superior e com isso, também pode haver uma diminuição dos processos no STF, sendo um avanço na questão da celeridade processual.

Com relação às questões urbanísticas relativas ao direito à moradia e ao cumprimento da função social da propriedade, necessário se faz notar que há parâmetros já definidos e que deveriam ser considerados para a formação, planejamento e organização de cidades mais justas. O direito à residência, à moradia, à propriedade consta na Declaração Universal dos Direitos Humanos, que, infelizmente, mais parece uma declaração apenas do que "deveria ser" e não que, efetivamente, se busca, quando o assunto se insere no contexto político, principalmente no Brasil.

Como contribuição foi possível observar como é importante a interposição de recursos perante as instâncias superiores, pois quando a lei municipal conflita com a Constituição Federal e as decisões são desfavoráveis em primeira e segunda instância, através de Recurso Extraordinário, é possível reverter essas decisões e adotar a Constituição no caso concreto sem declarar a inconstitucionalidade da lei. Também foi possível observar que a ação de usucapião é um imponente instrumento jurídico para legitimar e registrar uma propriedade em que os moradores eram apenas possuidores.

Como indicativo para estudos futuros, destaca-se a necessidade de maior abrangência do tema planejamento e zoneamento urbano das cidades. A observação de cidades que integrem diversos atores para melhor elaboração de planos diretores e leis municipais e também com a participação da sociedade civil, no sentido de democratizar as decisões quanto à área mínima para residências, dentre outros assuntos, pois, muitas vezes, as determinações da legislação municipal não condizem com a realidade da maioria da população, que fica desprovida de terrenos devidamente urbanizados.

No estudo de caso, foi relevante o posicionamento dos Ministros do STF, num julgamento que não mediu esforços para aplicar a Constituição Federal e julgar de forma 
fundamentada e sem lacunas, tendo em vista a repercussão geral da matéria, pois outros municípios podem também ter definido metragem mínima para lotes urbanos, o que não impede a pessoa que tem a posse de um imóvel com metragem inferior pleitear no Judiciário o direito de usucapir o local em que mora com sua família. Esse tipo de decisão traz um avanço para a sociedade, principalmente, para as pessoas com menor poder aquisitivo, que, muitas vezes, não tem sequer noção de seus direitos.

Por outro lado, houve uma preocupação, um estudo, a busca de informações com urbanistas, por parte do Relator, quanto às palavras que constariam no acórdão, para não torná-lo amplo demais, deixando de atentar apenas para a metragem mínima de lotes urbanos e colocando em risco outras normas municipais que precisam ser respeitadas para que não haja a ocupação de áreas de risco e de áreas de preservação ambiental.

Por fim, esclareceu o estudo, que, embora uma lei municipal possa fixar metragem mínima para lotes urbanos num patamar acima do previsto para a usucapião, a Constituição Federal é a lei maior e supera essas determinações municipais e garante o direito de propriedade a todos que cumprem os requisitos legais para adquirir-la, sem que, obrigatoriamente, a norma municipal seja considerada inconstitucional.

\section{REFERÊNCIAS BIBLIOGRÁFICAS}

AFONSO, Miguel Reis. ALMENDRA, Tânia Maria Nascimento. Usucapião como instrumento de regularização fundiária e sua prática. IN FERNANDES, Edésio. ALFONSIN, Betânia. A lei e a ilegalidade na produção do espaço urbano. Belo Horizonte: Del Rey, 2003. p. 3-17.

AGUIAR, L. A. F. e MIRANDA, E. A. O Impacto de Vizinhança no Contexto do Planejamento Urbano, Revista Espaço Aberto, PPGG - UFRJ, V. 5, N.2, p. 49-62, 2014ISSN 2237-3071

AlbuQuerQue, Ana Rita Vieira. Da Função Social da Posse. 1ạed. Rio de Janeiro: Editora Lumen Juris, 2002.

ALFONSIN, Betânia de Moares. Da invisibilidade à regularização fundiária. In FERNANDES, Edésio.A lei e a ilegalidade na produção do espaço urbano. Belo Horizonte: Del Rey, 2003. 
BRASIL. Constituição da República Federativa do Brasil de 1988. Disponível em http://www.planalto.gov.br/ccivil_03/constituicao/constituicaocompilado.htm Acesso em $23 / 01 / 2017$

BRASIL. Lei no 6.766, de 19 de dezembro de 1979. Dispõe sobre o Parcelamento do Solo Urbano e dá outras Providências. Disponível http://www.planalto.gov.br/ccivil_03/leis/L6766.htm Acesso em 23/01/2017

BRASIL. Lei no 10.257, de 10 de julho de 2001. Regulamenta os arts. 182 e 183 da Constituição Federal, estabelece diretrizes gerais da política urbana e dá outras providências. Disponível http://www.planalto.gov.br/ccivil_03/leis/LEIS_2001/L10257.htm Acesso em 23/01/2017

BRASIL. Lei no 10.406, de 10 de janeiro de 2002. Institui o Código Civil. Disponível em http://www.planalto.gov.br/ccivil_03/leis/2002/L10406.htm Acesso em 23/01/2017

BRASIL. Lei № 11.418, de 19 de dezembro de 2006. Acrescenta à Lei no 5.869, de 11 de janeiro de 1973 - Código de Processo Civil, dispositivos que regulamentam o § 3odo art. 102 da Constituição Federal. Disponível em https://www.planalto.gov.br/ccivil_03/_ato20042006/2006/lei/l11418.htm Acesso em 23/01/2017

BRASIL. Lei no 13.105, de 16 de março de 2015. Código de Processo Civil. Disponível em http://www.planalto.gov.br/ccivil_03/_ato2015-2018/2015/lei//13105.htmAcesso em $23 / 01 / 2017$

BRASIL. Supremo Tribunal Federal. RE 422349 / RS Recurso Extraordinário Relator(a) p/ Acórdão: Min. Dias Tóffoli Julgamento: 29/04/2015 Órgão Julgador: Tribunal Pleno Acórdão Eletrônico Repercussão Geral - Mérito DJe-153 divulg 04-08-2015 public 05-08-2015 Disponível em: http://www.stf.jus.br/portal/jurisprudencia/listarJurisprudencia.asp?s1=\%28RE\%24\%2ESCLA\%2 $E+E+422349 \% 2 E N U M E \% 2 E \% 29+O U+\% 28 R E \% 2 E A C M S \% 2 E+A D J 2+422349 \% 2 E A C M S \% 2 E \% 29 \& b$ ase=baseAcordaos\&url=http://tinyurl.com/d2drxjh Acesso em 23/01/2017.

CARMONA, Paulo Afonso Cavichioli. Direito Urbanístico. São Paulo. Saraiva: 2010. 
CAXIAS DO SUL. Lei no 3300 de 29 de novembro de 1988. Disponível em https://leismunicipais.com.br/a/rs/c/caxias-do-sul/lei-ordinaria/1988/330/3300/lei-ordinaria-n3300-1988-disciplina-o-parcelamento-do-solo-para-fins-urbanos-e-da-outras-providencias acesso em 23/01/2017

CAXIAS DO SUL. Lei no 6810 de 20 de dezembro de 2007. Disponível em https://leismunicipais.com.br/a/rs/c/caxias-do-sul/lei-ordinaria/2007/681/6810/lei-ordinaria-n6810-2007-disciplina-o-parcelamento-do-solo-para-fins-urbanos-a-regularizacao-fundiariasustentavel-e-da-outras-providencias acesso em 23/01/2017

CAXIAS DO SUL. Lei Complementar ㄲo 290 de 24 de setembro de 2007. Disponível em https://www.caxias.rs.gov.br/_uploads/planejamento/plano_diretor_lei.pdf acesso em $23 / 01 / 2017$

DOURADO, Sheilla Borges. A ilegalidade urbana e o meio ambiente. IN FERNANDES, Edésio. A lei e a ilegalidade na produção do espaço urbano. Belo Horizonte: Del Rey, 2003.

FERRAZ, Pedro Company. Análises sobre o usucapião especial urbano. Revista de Direito da Cidade, vol.02, no01. ISSN 2317-7721 p. 20-44.

FURTADO, Fernanda; REZENDE, V. L. F. M (2012). A questão metropolitana, regional e intermunicipal e os limites do planejamento municipal: uma discussão a partir do Estado do Rio de Janeiro. IN: Lucia Maria S. A. Costa; Denise B. Pinheiro Machado. (Org.). Conectividade e Resiliência: estratégias de projeto para metrópole. 1ed. Rio de Janeiro: RioBooks/PROURB, 2012, v. 1, p. 199-222.

GUIMARÃES, Virgínia Totti. Direito à cidade e direitos na cidade: integrando as perspectivas social, política e jurídica. Revista de Direito da Cidade vol. 09, no 2. ISSN 2317-7721 DOI: 10.12957/rdc.2017.27143, 2017.

HOSHINO, Thiago de Azevedo Pinheiro. MEIRINHO, Bruno César Deschamps. COELHO, Luana Xavier Pinto. Usucapião especial urbana como instrumento de regularização fundiária plena: 
desafios para um giro hermenêutico rumo à nova ordem jurídico-urbanística. Revista de Direito da Cidade, vol. 09, no 3. ISSN 2317-7721 pp. 972-1001. DOI: 10.12957/rdc.2017.27502, 2017.

IHERING, Rudolf Von. Teoria Simplificada da Posse. São Paulo: José Buschatsky, 1976.

LEITÃO, Lúcia. LACERDA, Norma. A função urbanística da usucapião. IN FERNANDES, Edésio. A lei e a ilegalidade na produção do espaço urbano. Belo Horizonte: Del Rey, 2003.

LOPES, Rodrigo. A cidade intencional: o planejamento estratégico de cidades. Rio de Janeiro. Mauad, 1998.

MACHADO, Denise Barcellos Pinheiro. Cidade Contemporânea e projetos urbanos. In Urbanismo: dossiê São Paulo- Rio de Janeiro. Maria Cristina Schicchi e Dênio Benfatti (org.). Campinas: PUCCAMP/PROURB, 2004.p. 91 a 102.

MENDES, Gilmar. O Controle da Constitucionalidade no Brasil. Disponível em http://www.stf.jus.br/repositorio/cms/portalStfInternacional/portalStfAgenda_pt_br/anexo/con trole_de_constitucionalidade_v_Port1.pdf Acesso em 06/07/2018. Supremo Tribunal Federal, 2004.

MIGUEL, Luciano Costa. O recurso extraordinário no novo CPC. Disponível em https://jus.com.br/artigos/37919/o-recurso-extraordinario-no-novo-cpc Acesso em 06/07/2018 NASCIMENTO, Tupinambá Miguel Castro do. Posse e Propriedade. 2. ed. rev. ampl. Porto Alegre: Livraria do Advogado, 2000.

PEREIRA, Marlene de Paula. Releituras da teoria possessória: da posse como projeção do direito de propriedade a um instituto autônomo e transformador da realidade. IN MOTA, Maurício (org.). Transformações do direito de propriedade privada. Rio de Janeiro: Elsevier, 2009.

ROLNIK, Raquel. A construção de uma política fundiária e de planejamento urbano para o país avanços e desafios. Revista políticas sociais - acompanhamento e análise | 12 | fev. 2006. Brasília: IPEA, 2006. 
SANCHES, Fernanda. Políticas Urbanas em renovação: Uma leitura crítica dos modelos emergentes. Revista Brasileira de Estudos Urbanos Regionais no 1/ maio 1999. DOI: http://dx.doi.org/10.22296/2317-1529.1999n1p115 p. 115-132 Disponível em http://unuhospedagem.com.br/revista/rbeur/index.php/rbeur/article/view/13 acesso em 15/02/2017.

SILVA, José Afonso da. Direito Urbanístico Brasileiro. 7ạ ED. Revista e atualizada. São Paulo. Malheiros: 2015.

SOUZA, Marcelo Lopes de (2015). Mudar a cidade: uma introdução crítica ao planejamento e à gestão urbanos. 10a Ed. Rio de Janeiro: Bertrand Brasil.

TORRES, Marcos Alcino. Impacto das novas ideias na dogmática do direito de propriedade. A multiplicidade dominial. IN MOTA, Maurício (org.). Transformações do direito de propriedade privada. Rio de Janeiro: Elsevier, 2009.

Trabalho enviado em 09 de julho de 2018

Aceito em 10 de dezembro de 2018 